\title{
FUNGSI - FUNGSI KELUARGA DENGAN HASIL PENGOBATAN TUBERCULOSIS PROGRAM DOTS
}

\author{
Ricky Riyanto Iksan ${ }^{1}$, Toha Muhaimin ${ }^{2}$, Syamsul Anwar ${ }^{3}$ \\ Akademi Keperawatan Pelni Jakarta ${ }^{1}$ \\ Universitas Indonesia ${ }^{2}$ \\ Universitas Muhammadiyah Jakarta ${ }^{3}$ \\ kykyiksan@gmail.com ${ }^{1}$
}

\begin{abstract}
ABSTRAK
Tujuan penelitian ini adalah untuk mengetahui fungsi keluarga dengan pengobatan TBC program DOTS di Wilayah Kerja Puskesmas Kabupaten Sumenep. Jenis penelitian ini adalah survei dengan menggunakan rancangan Cross Sectional. Hasil penelitian menunjukkan didapatkan variabel yang memiliki nilai $\mathrm{P}$ value $<0,05$ adalah variabel fungsi afektif, fungsi sosialisasi, dan fungsi perawatan keluarga dan tidak terdapat variabel yang memiliki nilai $P$ value $>0,05$. Simpulan, dari ketiga variabel independent yang dominan adalah fungsi afektif dalam keberhasiln pengobatan TB.
\end{abstract}

Kata Kunci : Teori Jean Watson, Tuberculosis Keluarga

\section{ABSTRACT}

This study aimed to determine the function of the family with TB treatment in the DOTS program in the Sumenep District Health Center. This type of research is a survey using a cross-sectional design. The results showed that variables with a P-value <0.05 were affective function, socialization functions, and family care functions, and there were no variables with a $P$ value $>0.05$. In conclusion, the three dominant independent variables are the affective function in the success of TB treatment.

Keywords: Jean Watson's Theory, Family Tuberculosis

\section{PENDAHULUAN}

Sepertiga penduduk dunia diperkirakan telah terinfeksi oleh Mycobacterium Tuberculosis (TB), TB Ialah penyakit yang menjadi perhatian dunia dengan berbagai upaya pengendalian yang dilakukan. Insiden dan kematian akibat tuberkulosis telah menurun namun tuberkulosis masih dalam kasus TB baru tersebut terdiri dari pria 5,4 juta jiwa, wanita 3,2 juta jiwa dan anak-anak 1,0 juta jiwa. Terdapat juga 1,5 juta jiwa akibat TB 1,1 juta orang diantaranya HIV negatif dan 0,4 juta orang diantaranya HIV positif, dimana sekitar 890.000 jiwa adalah pria, 480.000 jiwa adalah wanita dan 140 000 jiwa yaitu anak-anak tuberkulosis paru saat ini masih menjadi masalah kesehatan global. Sepertiga dari populasi penduduk diseluruh dunia sudah tertular dengan Tuberkulosis paru. Hal ini menyebabkan kesehatan yang buruk diantara jutaan orang setiap tahun dan menjadi penyebab utama kedua kematian dari penyakit menular diseluruh dunia setelah Human Immunodeficiency Virus (HIV) dan Acquired Immune Deficiency Syndrome (AIDS) World Health Organization (WHO, 2018). 
Data World Health Organization tahun 2018 menunjukkan bahwa tahun 2016 terdapat 10,4 juta kasus TB Paru didunia, 56\% kasus TB Paru berada di India, Indonesia, Cina, Filipina, dan Pakistan. Tahun 2016, sekitar 1,3 juta orang didunia meninggal karena TB Paru Sedangkan di Indonesia tahun 2016 terdapat 298 ribu penemuan kasus TB Paru dan 156 ribu penemuan kasus BTA Positif berdasarkan hasil cakupan penemuan kasus penyakit TB Paru (WHO, 2018).

Hasil riset Kementrian Kesehatan Repubik Indonesia 2018, menyebutkan bahwa jumlah prevalensi Tuberkulosis paru klinis yang tersebar di seluruh indonesia yaitu 1,0\% . beberapa Provinsi yang di antaranya mempunyai angka Prevalensi di atas angka Nasional yaitu: Provinsi Aceh, DKI Jakarta, Daerah Istimewa Yogyakarta, Sumatra barat, kepulauan Riau, Nusa Tengara Barat, Nusa Tengara Sulawesi selatan, Sulawesi tengah dan daerah timur Indonesia (Riskesdas, 2018). Angka keberhasilan pengobatan semua kasus TB (success rate ) sebesar 89\% dari target 85\%. Dengan succes rate lebih dari 90\% menggambarkan semakin banyak masyarakat yang menderita TB yang menyelesaikan pengobatan sampai tuntas.

Mayoritas penderita TB mengalami nyeri yang sangat saat batuk, dan juga mengalami sesak. Mekanisme koping tubuh dalam mengahadapi ini dengan mengeluarkan neuromodulator yang dapat menghambat transmisi impuls nyeri, salah satunya dengan menstimulasi beta-endorfin. Endorfin berperan untuk mengurangi sensasi nyeri dengan memblokir proses pelepasan substansi $\mathrm{p}$ dari neuron sensorik sehingga proses transmisi impuls nyeri di medula spinalis menjadi terhambat dan sensasi nyeri menjadi berkurang. Tingginya beta-endorfin juga memiliki dampak psikologis langsung yakni membantu memberi perasaan santai, mengurangi ketegangan, meningkatkan perasaan senang, membuat seseorang menjadi lebih nyaman, dan melancarkan pengiriman oksigen ke otot adalah usia produktif (Andri et al., 2019).

Dewasa ini pengobatan penyakit TB dimasyarakat diupayakan dengan meningkatkan produktifitas apa yang mereka bisa lakukan supaya mereka bisa hidup secara normal meski dalam kondisi pemulihan penyakitnya. Impact-nya adalah masyarakat terbebas dari masalah-masalah sosial ekonomi yang diakibatkan karena penyakit TB. Angka keberhasilan pengobatan TB (Succes Rate) Provinsi Jawa Timur Tahun 2013-2016 No Indikator Program succses rate, Target Nas> 85\%, Target Jatim> 90 \%,2013 91\%, 2014 91\%, 2015 91\%, 2016 89,91\% (Kementerian Kesehatan RI, 2017).

Besarnya tantangan dalam penanggulangan penyakit TB dapat dilihat dari hasil survey prevalensi tuberkulosis Kemenkes tahun 2013-2014, angka insiden TB adalah 399 per 100.000 penduduk, dan angka prevalensi TB sebesar 647 per 100.000 penduduk. Jika jumlah penduduk Indonesia berkisar 250 juta orang, maka diperkirakan ada sekitar 1 juta pasien TB baru dan ada sekitar 1,6 juta pasien TB setiap tahunnya. Sedangkan jumlah kematian karena TB 100.000 orang per tahun, atau 273 orang per hari. Situasi tersebut menyebabkan Indonesia menempati peringkat ke-2 negara yang memiliki beban TB tinggi di dunia, setelah India (Kementerian Kesehatan, 2017)

Berdasarkan data yang diperoleh dari dinas kesehatan Penyakit baru dengan BTA+ 626 kasus, dengan angka kesembuhan pada tahun 2016 sebesar 790 kasus dari 944 kasus yang di obati dengan angka keberhasilan (success rate) 92,27 (Dinkes Sumenep, 2016).

Penelitian Laili tahun 2020 menunjukkan bahwa nilai signifikansi fungsi keluarga (apgar family) terhadap keberhasilan pengobatan tuberculosis paru sebesar 0.000, artinya terdapat pengaruh yang signifikan $(\mathrm{p}<0.05)$. Koefisien korelasi fungsi keluarga 
dengan apgar family terhadap keberhasilan pengobatan tuberkulosis paru sebesar 0.808 , artinya terdapat pengaruh yang sangat kuat antara fungsi keluarga (apgar family) terhadap keberhasilan pengobatan tuberculosis paru di Puskesmas Omben. Simpulan fungsi keluarga memiliki pengaruh (Laili et al., 2020).

Penelitian Febrina (2018) menyatakan bahwa peran keluarga sebagai PMO bagi pasien TB paru dalam mengawasi, memotivasi, memastikan pemeriksaan ulang sputum, dan memberikan edukasi kepada pasien TB, akan membantu proses kesembuhan bagi pasien TB paru.

Dengan proses afektif, sosialisasi dan perawatan keluarga yang sangat mempengaruhi dalam pengobatan dimana pasien bisa sembuh dengan baik apabila dari perawatan keluarga yang baik dan mengikuti prosedur yang benar dari rumah sakit ke rumah dan yang mempengaruhi dalam proses pengobatan.

Penelitian Tamamengka et al., (2019) hasil penelitian di dapat p-value sebesar 0,001 dan $0,003(\leq \alpha 0,05)$ yang berarti ada hubungan yang signifikan kesimpulan hasil penelitian ini menunjukan bahwa ada hubungan fungsi afektif dan perawatan keluarga dengan kepatuhan pengobatan TB paru di Puskesmas Tuminting Manado.

Salah satu dari komponen DOTS (Directly Observed Treatment Shortcourse) adalah pengobatan panduan OAT jangka pendek dengan pengawasan langsung. Untuk menjamin keteraturan pengobatan diperlukan Pengawas Menelan Obat (PMO) dengan persyaratan yaitu seseorang yang dikenal, dipercaya dan disetujui baik oleh petugas kesehatan maupun penderita, selain itu harus disegani dan dihormati oleh penderita, seseorang yang tinggal dekat dengan penderita, bersedia membantu penderita dengan sukarela (Kementerian Kesehatan RI, 2018).

Berdasarkan studi pendahuluan yang dilakukan pada tanggal 05 Desember 2018 di Puskesmas wilayah kabupaten sumenep dengan mewawancarai 121 orang keluarga pasien TB Paru, didapatkan ada 121 orang anggota keluarga mengatakan tidak mengetahui secara detail fungsi perawatan kesehatan keluarga, hanya tahu kalau TB paru menular dan harus membawanya berobat. Sedangkan dua orang lainnya mengatakan telah mengetahui sebagian besar fungsi perawatan keluarga dan cara merawat anggota keluarga yang menderita TB paru. Kesehatan pada dewasa terutama pada tingkat pelayanan pertama mampu secara maksimal berfokus pada upaya promotif dan preventif dalam upaya kunjungan rumah penyebaran TB sehingga bisa memakai penerapan teori Jean Watson pada proses asuhan keperawatan menekankan pada caring menurut Jean Watson percaya caring adalah inti dari praktik keperawatan. Selain itu Jean Watson juga menekankan bahwa suatu praktik keperawatan dalam hal ini perawat yang professional adalah praktik yang menggabungkan ilmu, seni, nilai kemanusiaan dan human care.

Hasil penelitian sebelumnya mengunakan pendekatan kelurga secara afektif tetapi tidak menggabungkan fungsi keluarga yang lainya. Namun penelitian ini melakukan pendekatan keluarga dengan fungsi afektif, sosialisasi dan perawatan keluarga. Penelitian ini bertujuan untuk mempelajari sejauh mana fungsi keluarga dalam hasil pengobatan pasien TB peserta DOTS di Wilayah Puskesmas Kabupaten Sumenep.

\section{METODE PENELITIAN}

penelitian ini merupakan penelitian dengan menggunakan rancangan Cross Sectional dalam suatu penelitian Cross Sectional adalah variabel sebab atau resiko dan akibat atau kasus yang terjadi pada objek penelitian diukur atau dikumpulkan secara simultan dalam waktu yang bersamaan. Dalam suatu pengumpulan data untuk jenis 
penelitian ini, baik untuk variabel sebab (independent variable), maupun variabel akibat (dependent variable), dilakukan secara bersama-sama atau sekaligus. Populasi dalam penelitian adalah orang yang menderita TB paru yang masih menjalani pengobatan rawat jalan di Wilayah Puskesmas Kabupaten Sumenep pada tangal 10 Februari s/d 10 April 2019 yang berjumlah 120 orang.

Pemilihan sampel dilakukan sesuai kriteria inklusi dan kriteria ekslusi, kriteria inklusi yaitu keluarga yaitu mempunyai angota keluarga TB paru yang berobat Di Puskesmas Wilayah Sumenep dan Pasien yang yang bersedia menjadi responden. Kemudia dari sampel tersebut akan dilakukan kelompok perlakuan dan kelompok kontrrol. Proposal penelitian mendapatkan persetujuan dan sudah lulus kaji etik di Universitas Muhammadiyah Jakarta.

\section{HASIL PENELITIAN \\ Analisis Univariat \\ Karakteristik Responden}

Tabel. 1

Distribusi Frekuensi Responden Hasil Pengobatan Tuberculosis Program DOTS pada Dewasa Berdasarkan Variabel Dependen, Independen, dan Counfonding

\begin{tabular}{lcc}
\hline \multicolumn{1}{c}{ Variabel } & Jumlah (n) & Persentase (\%) \\
\hline Pengobatan TB Paru & & \\
Sembuh & 76 & 63,3 \\
Tidak Sembuh & 44 & 36,7 \\
\hline Fungsi Afektif & 70 & \\
Baik & 50 & 58,3 \\
Tidak baik & & 41,7 \\
\hline Fungsi Sosialisasi & 69 & 57,5 \\
Baik & 51 & 42,5 \\
Tidak baik & & \\
\hline Fungsi Perawatan Keluarga & 73 & 60.8 \\
Baik & 47 & 39,2 \\
Tidak baik & & \\
\hline Umur & 23 & 19,2 \\
S25 Tahun & 97 & 80,8 \\
$>25$ Tahun & & \\
\hline Jenis Kelamin & 38 & 61.7 \\
Laki-Laki & 82 & \\
Perempuan & & 72,5 \\
\hline Pendidikan & 87 & 27,5 \\
Rendah & 33 & \\
Tinggi & &
\end{tabular}

Berdasarkan tabel 1 menunjukan bahwa distribusi frekuensi pengobatan TB paru yang sembuh mengalami peningkatan dibanding yang tidak sembuh, fungsi afektif, sosialisasi, dan perawatan keluarga menunjukan adanya tingkat kesembuhan yang baik pada pasien dalam pengobatan TB paru. Dari hasil penelitian ini menunjukan bahwa umur diatas 25 tahun lebih dominan di banding umur yang di bawah 25 tahun, dalam penelitian ini pasien jenis kelamin perempuan lebih banyak di banding laki-laki begitu dengan tingkat pendidikan masyarakat yang rendah sehinga perlunya akan perbaikan pada pasien pengobatan TB paru. 


\section{Analisis Bivariat}

Tabel. 2

Analisis Hubungan Data Demografi, Variabel Independen dengan Hasil Pengobatan Tuberculosis Program DOTS pada Dewasa

\begin{tabular}{|c|c|c|c|c|c|c|c|c|}
\hline \multicolumn{9}{|c|}{ Hasil Pengobatan TB Paru } \\
\hline \multirow[t]{2}{*}{ Variabel } & \multicolumn{2}{|c|}{ Sembuh } & \multicolumn{2}{|c|}{$\begin{array}{l}\text { Tidak } \\
\text { Sembuh }\end{array}$} & \multicolumn{2}{|c|}{ Total } & \multirow[t]{2}{*}{ P-value } & \multirow{2}{*}{$\begin{array}{c}\text { OR } \\
95 \% \mathrm{CI}\end{array}$} \\
\hline & $\mathrm{N}$ & $\%$ & $\mathrm{~N}$ & $\%$ & $\mathrm{~N}$ & $\%$ & & \\
\hline Fungsi Afektif & & & & & & & & 7.154 \\
\hline Baik & 57 & 81,4 & 13 & 18,6 & 70 & 100 & 0.000 & $(3,119-16.047)$ \\
\hline Tidak baik & 19 & 38,0 & 31 & 62,0 & 50 & 100 & & \\
\hline \multicolumn{9}{|c|}{ Fungsi Sosialisasi } \\
\hline Baik & 51 & 73,9 & 18 & 26,1 & 69 & 100 & \multirow[t]{2}{*}{0,005} & 2.947 \\
\hline Tidak baik & 25 & 49,0 & 26 & 51,0 & 51 & 100 & & \\
\hline \multicolumn{9}{|c|}{ Fungsi Perawatan Keluarga } \\
\hline Baik & 55 & 75,3 & 18 & 24,7 & 73 & 100 & \multirow{2}{*}{0,001} & 3.783 \\
\hline Tidak Baik & 21 & 44,7 & 26 & 55,3 & 43 & 100 & & $(1.728-8.282)$ \\
\hline
\end{tabular}

Berdasarkan tabel 2 menunjukkan ada hubungan fungsi afektif dengan keberhasilan hasil pengobatan TB paru di Wilayah Puskesmas Kabupaten Sumenep dengan nilai $P$-value sebesar $0.000<\alpha(0,05)$ dan nilai OR 7.154. Ada hubungan fungsi sosialisasi dengan keberhasilan hasil pengobatan TB Paru di Wilayah Puskesmas Kabupaten Sumenep dengan nilai $P$-value $0.005<\alpha(0,05)$ dan nilai OR 2.94. Ada hubungan fungsi perawatan keluarga dengan hasil pengobatan TB Paru di Wilayah Puskesmas Kabupaten Sumenep dengan nilai $P$-value $0,001<(0,05)$ Dan nilai OR. 3.783. Dari ke tiga variabel independent yang dominan adalah fungsi afektif nilai $p$ value yang lebih kecil dari < $(0,05)$ dan nilai OR lebih 7.154 kali memiliki resiko baik dalam keberhasiln pengobatan TB paru adalah fungsi afektif.

\section{Analisis Multivariat}

Seleksi Bivariat masing-masing variabel independen dilakukan analisis bivariat dengan variable dependen. Analisis bivariate menghasilkan nilai $P$-value $<0.25$ maka variable tersebut masuk sebagai variable kandidat Multivariat. Jika analisis bivariate menghasilkan p-value > 0,25 maka variabel tersebut dikeluarkan, namun bila secara substansi penting, maka variabel tersebut dapat dimasukkan dalam model multivariat.

Tabel. 3

Hasil Pengelompokan dan Seleksi Bivariat Fungsi-Fungsi Keluarga dengan Hasil Pengobatan Tuberculosis Program DOTS pada Dewasa

\begin{tabular}{lcc}
\hline \multicolumn{1}{c}{ Variabel } & Nilai p-value & Kandidat \\
\hline Fungsi Efektif & 0,000 & $\sqrt{ }$ \\
Fungsi Sosialisasi & 0,005 & $\sqrt{ }$ \\
Fungsi Perawatan Keluarga & 0,001 & $\sqrt{ }$ \\
Usia & 0,835 & - \\
Jenis Kelamin & 0,704 & - \\
Pendidikan & 0,934 & - \\
\hline
\end{tabular}


Berdasarkan tabel 3 didapatkan bahwa ada 3 variabel yang masuk dalam kandidat dan masuk dalam seleksi multivariat dengan nilai $P$-value $<0,25$ diantaranya; Fungsi Afektif, Fungsi Sosialisasi, dan Fungsi Perawatan Keluarga. Sedangkan yang tidak di masukan dalam permodelan multivariat yaitu: usia, jenis kelamin, dan pendidikan.

Pemodelan Regresi Logistik Multivariat analisis fungsi-fungsi keluarga dengan hasil pengobatan tuberculosis program dots pada Dewasa di Wilayah Puskesmas Kabupaten Sumenep. Analisis selanjutnya dilakukan untuk mengetahui variabel yang paling dominan secara bersama-sama dari variabel-variabel yang mempunyai hubungan dan juga variabel yang memiliki nilai $\mathrm{p}<0,25$. Analisis dilakukan dengan menggunakan uji statistik regresi logistik ganda dengan metode backward $L R$.

Tabel. 4

Hasil Pemodelan Regresi Logistik Multivariat Pertama Fungsi Keluarga dengan Hasil Pengobatan Tuberculosis Program DOTS pada Dewasa

\begin{tabular}{llccc}
\hline No & \multicolumn{1}{c}{ Variabel } & P-value & OR & $95 \%$ \\
& & & & CI \\
\hline 1. & Fungsi Afektif & 0.000 & 7.154 & $3.319-16.407$ \\
2. & Fungsi Sosialisasi & 0.023 & 2.947 & $1.367-6.353$ \\
3. & Fungsi Perawatan & 0.021 & 3.783 & $1.728-8.282$ \\
& Keluarga & & & \\
\hline
\end{tabular}

Pada tabel 4 didapatkan variabel yang memiliki $\mathrm{P}$ value $<0,05$ adalah variabel fungsi afektif, fungsi sosialisasi, dan fungsi perawatan keluarga dan tidak terdapat variabel yang memiliki nilai $\mathrm{P}$ value $>0,05$.

\section{PEMBAHASAN}

Hasil menunjukkan bahwa fungsi afektif dengan keberhasilan Pengobatan TB paru di Wilayah Kerja Puskesmas Kabupaten Sumenep yang fungsi afektifnya kurang baik/tidak baik dari pada kolom sembuh menunjukkan tingkat kesembuhan pasien sangat baik dimana fungsi ini dapat berperan aktif dalam proses penyembuhan pasien TB paru.

Hasil penelitian Pradana et al., (2018) Tuberkulosis merupakan penyakit yang dapat menular dan untuk sembuh pasien harus meminum obat secara rutin dalam jangka waktu yang cukup lama yakni 6 bulan, didalam pengobatannya pasien tuberkulosis di tuntut untuk patuh minum obat dan untuk patuh sendiri di pengaruhi beberapa faktor diantaranya adalah dukungan keluarga. Penelitian ini untuk mengidentifikasi adakah hubungan dukungan keluarga dengan kepatuhan minum obat pada pasien tuberkulosis paru di puskesmas Guntur Demak. Hasil penelitian menunjukkan bahwa 52,7\% responden 26-35 tahun, 74,5\% responden dengan jenir kelamin laki-laki, 87,3\% responden bekerja sebagai wiraswasta, $47 \%$ responden dengan pendidikan SD, 59,1\% responden dengan dukungan keluarga positif. 63,6 patuh dalam pengobatan tuberkulosis terdapat hubungan dukungan keluarga dengan kepatuhan minum obat pada pasien tuberkulosis paru di puskesmas Guntur Demak dengan p-value 0,001.

Hasil penelitian yang dilakukan oleh Laili tahun 2020 di Puskesmas Omben hasil uji Spearman menunjukkan nilai signifikansi fungsi keluarga (apgar family) terhadap keberhasilan pengobatan tuberculosis paru sebesar 0.000, artinya terdapat pengaruh yang signifikan $(\mathrm{p}<0.05)$. Koefisien korelasi fungsi keluarga dengan apgar family 
terhadap keberhasilan pengobatan tuberculosis paru sebesar 0.808, artinya terdapat pengaruh yang sangat kuat antara fungsi keluarga (apgar family) terhadap keberhasilan pengobatan tuberculosis paru di Puskesmas Omben. Fungsi keluarga (apgar family) memiliki pengaruh yang sangat kuat terhadap keberhasilan pengobatan tuberculosis paru di Puskesmas Omben (Laili et al., 2020).

Pendampingan minum obat pada penderita TB dengan melibatkan keluarga sangat penting bagi penderita, mengingat keluarga adalah orang yang setiap hari ada didekatnya dan turut berisiko terkena penularan TB. Selain itu, TB merupakan penyakit dengan lama minum obat selama 6 bulan secara berturut-turut, sehingga jika keluarga dilibatkan dalam program pendampingan ini, penderita akan merasakan dukungan yang kuat dari keluarga dalam menjalani proses penyembuhan dan minum obat (Puspitha et al., 2020). Hal ini sejalan dengan penelitian yang dilakukan oleh Nesi et al., (2017) bahwa ada hubungan dukungan dan pengetahuan keluarga dengan tingkat kepatuhan berobat.

Hal ini didukung pada penelitian oleh Sari et al., (2017) hasil penelitian menunjukan adanya hubungan yang bermakna 6 antara motivasi pasien TB paru dengan kepatuhan dalam mengikuti program pengobatan sistem DOTS, yang dihubungkan dengan $(\mathrm{p}$ value $)=0.0001$ lebih kecil dari pada alpha $=0,05$ sehingga hipotesis nol ditolak, berarti ada hubungan antara motivasi dengan kepatuhan.

Fungsi Perawatan/pemeliharaan kesehatan keluarga merupakan suatu fungsi untuk mempertahankan keadaan kesehatan anggota keluarga agar tetap memiliki produktivitas tinggi. Fungsi fisik keluarga dipengaruhi oleh orang tua yang menyediakan makanan, pakaian, tempat tinggal, perawatan kesehatan, dan perlindungan terhadap bahaya. Pelayanan dan praktik kesehatan (yang mempengaruhi status kesehatan anggota keluarga secara individual) merupakan fungsi keluarga yang paling relevan.

Peran keluarga dalam memberikan perawatan dan dukungan psikososial kepada penderita TB sangat penting. Dukungan dan perawatan yang diberikan oleh anggota keluarga memberikan kontribusi yang cukup besar terhadap pengendalian TB. Walaupun anggota keluarga mungkin tidak bisa menggantikan keahlian profesional petugas kesehatan, namun kehadirannya sangat membantu dalam merawat dan mengawasi kepatuhan meminum obat, sehingga mampu mengurangi tingkat kesalahan dan kegagalan pengobatan. Selain itu, keluarga juga sangat berperan dalam hal dukungan sosial dan emosional, serta memotivasi untuk menyelesaikan pengobatan. Dukungan keluarga bisa dalam bentuk pendampingan perawatan, mengingatkan untuk minum obat-obatan, menyediakan makanan yang bergizi, memotivasi untuk sembuh, dan dukungan psikososial lainnya. Oleh karena itu, perlu dilakukan pemberdayaan orang terdekat (keluarga) dalam membantu mengendalikan TB (Puspitha et al., 2020).

Hasil penelitian di lakukan oleh Hanif (2018) metode penelitian ini menggunakan metode deskriptif analisis kemudian data diolah dengan menggunakan uji chi square. Sampel dalam penelitian ini sebanyak 66 orang responden. Hasil uji statistik diperoleh $\mathrm{p}$ value $=0,000(\mathrm{p})$. Kesimpulan dalam penelitian ini peran perawatan keluarga adalah ada hubungan efikasi diri pasien TB Paru dengan kepatuhan minum obat dalam mengikuti program pengobatan sistem DOTS di Polklinik Paru RSUD Dr.Achmad Mochtar Bukittinggi tahun 2018.

Dalam permodelan multivariat di dapatkan hasil seleksi dalam bivariate bahwa terdapat nilai $\mathrm{p}$ value tidak ada yang $>0,05$ sehingga tidak dilakukan uji regresi logistic pemodelan akhir. Berdasarkan permodelan multivariate dari 6 variabel independen yang termasuk dalam permodelan pertama dan yang berpengaruh dalam pengobatan TB paru 
diantaranya fungsi afektif, fungsi sosialisasi dan perawatan keluarga. mengetahui hubungan efikasi diri pasien TB paru dengan kepatuhan minum obat.

Hasil penelitian Parera et al., (2019) bahwa program penemuan kasus, pengobatan pasien TB dan promosi kesehatan dilakukan $100 \%$ oleh responden di puskesmas. Program pemeriksaan sputum dilakukan dengan baik oleh $18(81,8 \%)$ responden petugas laboratorium TB. Hal ini terkait dengan suspek TB tidak mengembalikan pot dahak ke puskesmas. Petugas program TB dan petugas laboratorium memiliki tugas rangkap, kondisi demografi yang jauh dan sulit di jangkau dengan kendaraan. Pemilihan tempat untuk kegitatan promosis TB dan lokasi puskesmas yang jauh dari tempat tinggal masyarakat. kondisi laboratorium yang kecil dan harusnya terpisah untuk TB. Sputum yang di berikan petugas pemegang program kepada petugas laboratorium juga kualitasnya kurang baik. menunjukkan bahwa program penemuan kasus, pengobatan pasien TB dan promosi kesehatan dilakukan $100 \%$ oleh responden di puskesmas. Program pemeriksaan sputum dilakukan dengan baik oleh $18(81,8 \%)$ responden petugas laboratorium TB. Hal ini terkait dengan suspek TB tidak mengembalikan pot dahak ke puskesmas. Petugas program TB dan petugas laboratorium memiliki tugas rangkap, kondisi demografi yang jauh dan sulit di akses dengan kendaraan. Pemilihan tempat untuk kegitatan promosis TB dan lokasi puskesmas yang jauh dari tempat tinggal masyarakat. Kondisi laboratorium yang kecil dan harusnya terpisah untuk TB. Sputum yang diberikan petugas pemegang program kepada petugas laboratorium juga kualitasnya kurang baik.

\section{SIMPULAN}

Ada hubungan fungsi afektif dengan keberhasilan hasil pengobatan TB paru di Wilayah Puskesmas Kabupaten Sumenep. Ada hubungan fungsi sosialisasi dengan keberhasilan hasil pengobatan TB Paru di Wilayah Puskesmas Kabupaten Sumene, ada hubungan fungsi perawatan keluarga dengan hasil pengobatan TB paru di Wilayah Puskesmas Kabupaten Sumenep.

\section{SARAN}

\section{Bagi Keperawatan Komunitas}

Memberikan kontribusi dalam pengembangan Ilmu keperawatan khususnya keperawatan komunitas terkait dengan Fungsi keluarga afektif, fungsi sosialisasi, fungsi perawatan keluarga dan mampu mengembangkan intervensi yang sesuai dengan Fungsi keluarga tersebut.

\section{Bagi Puskesmas}

Bagi puskesmas, diharapkan dapat bermanfaat sebagai masukan untuk menentukan kebijakan lebih lanjut khusunya program pengobatan TB paru.

\section{Pendidikan Keperawatan}

Dapat memberikan informasi dalam rangka mendukung teori yang berkaitan dengan fungsi keluarga dengan hasil pengobatan tuberkulosis program DOTS Hasil penelitian ini diharapkan dapat memberikan sumbangan bagi pengembangan ilmu pengetahuan khususnya membantu keluarga penderita TBC paru dalam program pengobatan. 


\section{Bagi Peneliti Selanjutya}

Hasil penelitian selanjutya diharapkan dapat memberikan sumbangan pemikiran kepada para peneliti berikutnya atau petugas kesehatan lainnya, dalam penanggulangan TB paru ini.

\section{DAFTAR PUSTAKA}

Andri, J., Karmila, R., Padila, P., Harsismanto, J., \& Sartika, A. (2019). Pengaruh Terapi Aktivitas Senam Ergonomis terhadap Peningkatan Kemampuan Fungsional Lansia. Journal of Telenursing, 1(2), 304-313. https://doi.org/https://doi.org/10.31539/joting.v1i2.933

Febrina, W. (2018). Analisis Peran Keluarga sebagai Pengawas Minum Obat (PMO) Pasien TB Paru. Human Care Journal, 118. https://doi.org/10.32883/hcj.v3i2.66

Hanif, M. (2018). Hubungan Efikasi Diri Pasien TB Paru dengan Kepatuhan Minum Obat Dalam Mengikuti Program Pengobatan Sistem DOTS di Polklinik Paru RSUD Dr. Achmad Mochtar Bukittinggi. In Sekolah Tinggi Ilmu Kesehatan Perintis. https://doi.org/10.22201/fq.18708404e.2004.3.66178

Kementerian Kesehatan RI. (2017). Juknis Penemuan Aktif TBC Integrasi Program Indonesia Sehat melalui Pendekatan Keluarga (PISPK). Direktorat Jenderal Pencegahan dan Pengendalian Penyakit Kementerian Kesehatan

Kementerian Kesehatan RI. (2017). Pedoman Nasional Penanggulangan Tuberkulosis

Kementerian Kesehatan RI. (2018). Infodatin Tuberkulosis. Pusat Data dan Informasi Kementerian Kesehatan RI, 1. https://www.depkes.go.id/article/view/18030500005/waspadai-peningkatanpenyakit-menular.html\%0Ahttp://www.depkes.go.id/article/view/17070700004/ program-indonesia-sehat-dengan-pendekatan-keluarga.html

Laili, N., Endra, F., \& Isbandiyah, I. (2020). Hubungan Fungsi Keluarga (Apgar Family) terhadap Keberhasilan Pengobatan Tuberculosis Paru di Puskesmas Omben. Universitas Muhammadiyah Malang

Nesi, A., Subekti, I., \& Putri, R. M. (2017). The Relationship Between the Family Support and Awareness (Knowledge) and the Lung TB Patient's Faithfulness in Undergoing Treatment at Maubesi Health Centre Mid-North Timor District. Nursing News, 2(2), 371-379. https://doi.org/10.1021/BC049898Y

Parera, L., Suharyo, S., \& Lukmono, D. T. H. (2019). Evaluasi Program Pengendalian Tuberculosis di Wilayah Kerja Puskesmas di Kota Ambon [Universitas Diponegoro Semarang]. eprints.undip.ac.id/76792/1/cover lodri_parera.pdf

Pradana, W. K., Ardian, I., \& Haiya, N. N. (2018). Hubungan Dukungan Keluarga dengan Kepatuhan Minum Obat pada Pasien Tuberkulosis Paru di Puskesmas Guntur Demak. Universitas Islam Sultan Agung Semarang

Puspitha, A. R., Erika, K. A., \& Saleh, U. (2020). Pemberdayaan Keluarga dalam Perawatan Tuberkulosis. Media Karya Kesehatan, 3(1), 50-58

Riskesdas. (2018). Hasil Utama Riset Kesehatan Dasar. Kementrian Kesehatan Republik Indonesia, 1-100. https://doi.org/1

Sari, I. D., Mubasyiroh, R., \& Supardi, S. (2017). Hubungan Pengetahuan dan Sikap dengan Kepatuhan Berobat pada Pasien TB Paru yang Rawat Jalan di Jakarta Tahun 2014. Media Penelitian dan Pengembangan Kesehatan, 26(4). https://doi.org/10.22435/mpk.v26i4.4619.243-248 
Sumenep, D. K. K. (2016). Profil Kesehatan Kabupaten Sumenep Tahun 2016 (Data 2015). In Dinas Kesehatan Kabupaten Sumenep. https://doi.org/10.1080/09603100150210228

Tamamengka, D., Kepel, B., \& Rompas, S. (2019). Fungsi Afektif dan Perawatan Keluarga dengan Kepatuhan pengobatan TB Paru. E-Journal Keperawatan (E-Kp), $7(2), 1-10$

WHO. (2018). Global Tuberculosis Report WHO 2018. In WHO report (Vol. 69, Issue 4) 